\title{
PENGARUH PENGEMBANGAN KARIR TERHADAP KINERJA KARYAWAN MELALUI PEMEDIASI MOTIVASI KERJA KARYAWAN
}

\author{
Ammar Balbed ${ }^{1}$ \\ Desak Ketut Sintaasih ${ }^{2}$
}

${ }^{1,2}$ Fakultas Ekonomi Dan Bisnis Universitas Udayana, Bali, Indonesia

E-mail: amarbalbed10@gmail.com

\begin{abstract}
ABSTRAK
Kinerja karyawan merupakan faktor penting untuk kelangsungan hidup perusahaan. Tujuan penelitian ini adalah untuk menganalisis pengaruh pengembangan karir dan motivasi kerja terhadap kinerja karyawandan pengaruh pengembangan karir terhadap kinerja karyawan melalui pemediasi motivasi kerja. Populasi dan sampel pada penelitian ini adalah seluruh karyawan PT. Kanmo Group pada brand Havaianas yang berjumlah 64 orang. Data di analisis menggunakan teknik analisis jalur. Hasil analisis data menunjukkan bahwapengembangan karir dan motivasi kerja berpengaruh positif dan signifikan terhadapkinerja karyawan, pengembangan karir berpengaruh positif terhadap motivasi kerja, serta motivasi kerja mampu memediasi pengaruh pengembangan karir terhadap kinerja karyawan. Kinerja karyawan dapat ditingkatkan dengan menjaga ataupun meningkatkan pengembangan karir dan motivasi kerja karyawan.
\end{abstract}

Kata Kunci: pengembangan karir,motivasi kerja, kinerja karyawan

\section{ABSTRACT}

Employee performance is an important factor for company's sustainability. The purpose of this study was to analyze the effect of career development and work motivation on employee performance and the influence of career development on employee performance through mediating work motivation. The population and sample in this study are all employees of PT. Kanmo Group in the Havaianas brand of 64 people. Data were analyzed using path analysis techniques. The results of data analysis show that career development and work motivation have a positive and significant effect on employee performance, career development has a positive effect on work motivation, and work motivation can mediate the influence of career development on employee performance. Employee performance can be improved by maintaining or enhancing career development and employee motivation.

Keywords: career development, work motivation, employee performance 


\section{PENDAHULUAN}

Masalah sumber daya manusia menjadi tolok ukur bagi perusahaan untuk tetap dapat bertahan. Sumber daya manusia merupakan peran utama dalam setiap kegiatan yang dilakukan perusahaan. Walaupun banyaknya sarana dan prasarana serta sumber daya, tanpa dukungan sumber daya manusia kegiatan perusahaan tidak akan berjalan dengan baik. Dengan demikian sumber daya manusia merupakan kunci pokok yang harus diperhatikan dalam mewujudkan tujuan perusahaan. Selain itu, perusahaan juga dituntut untuk memikirkan, merancang dan mengeksekusi resolusi baru agar dapat memenuhi tuntutan perkembangan zaman. Upaya meningkatkan kualitas sumber daya manusia yang terlibat dalam proses bisnis perusahaan merupakan salah satu upaya yang ditempuh oleh para pelaku bisnis untuk memenuhi tuntutan perkembangan zaman dan memenangkan kompetisi pada pasar global. Tujuannya adalah untuk mendapatkan peluang yang lebih baik untuk dapat menjadi market leader sesuai dengan tuntutan (Kotler dalam Suwandi, 2016).

PT. Kanmo Group berdiri sebagai anak perusahaan dari K. Aloomall Group yang didirikan di Indonesia pada tahun 1940. Pada tahun 2005, PT. Kanmo Group dibentuk sebagai anak perusahaan retail dari grup tersebut yang berfokus pada pendistribusian retail di Indonesia dan memperluas pasar industri pada segmen bayi dan anak, serta fashion dan aksesoris. Brand yang dinaungi oleh PT. Kanmo Group, yaitu Mothercare, Coach, Early Learning Centre, dan Gingersnaps. Pada tahun 2017 perusahaan ini memperluas segmen pasarnya dengan mengambil alih brand sandal Havaianas. Havaianas kini telah dikenal sebagai brand internasional yang mampu membawa kultur dan gaya Brazil ke lebih 100 negara diseluruh 
dunia. Banyaknya perusahaan yang beroperasi dalam bidang yang sama membuat tingkat pesaing menjadi meningkat,keunggulan bersaing dapat tercapai jika perusahaan memiliki sumber daya manusia yang berkualitas, kompeten dan memiliki kinerja yang tinggi.

Kinerja adalah tingkat hasil kerja karyawan dalam mencapai persyaratanpersyaratan pekerjaan yang diberikan perusahaan. Kinerja juga diartikan hasil kerja karyawan baik dilihat dari kualitas maupun kuantitas, berdasarkan standar kerja yang telah ditentukan (Palgunanto dkk., 2010: 67). Kinerja adalah suatu hasil kerja yang dicapai seseorang dalam melaksanakan tugas yang dibebankan kepada yang didasarkan atas kecakapan, pengalaman kesungguhan serta waktu (Riyadi, 2011).

Banyak faktor yang dapat mempengaruhi kinerja seseorang. Salah satunya adalah pengembangan karir, sehingga karyawan berupaya dapat menyelesaikan pekerjaannya dengan lebih baik (Rivai dalam Febriansyah, 2016). Pengembangan karir merupakan proses peningkatan kemampuan kerja seorang karyawan yang mendorong meningkatnya kinerja dalam rangka mencapai karir yang diinginkan. Pengembangan karir yang didukung oleh perusahaan, mengharapkan adanya umpan balik dari karyawanberupa kinerja yang baik.Menurut Marwansyah (2014:208) pengembangan karir adalah kegiatan-kegiatan pengembangan diri yang ditempuh oleh seseorang untuk mewujudkan rencana karier pribadinya. Penelitian yang dilakukan oleh Pratiwi (2015) mendapatkan hasil bahwa pengembangan karir berpengaruh positif terhadap kinerja karyawan. Hasil penelitian Oduma (2014) pengembangan karir berpengaruh positif terhadap 
kinerja karyawan. Penelitian Parerung (2014) juga menunjukkan bahwa pengembangan karir berpengaruh terhadap kinerja karyawan. Hal ini menunjukkan dengan adanya pengembangan karir, karyawan merasa adanya kepastian dalam karir yang akandiraih di masa yang akan dating, sehingga diimbangi dengan memberikan kinerja yang optimal.

Selain meningkatkan kinerja karyawan, pengembangan karir yang baik juga dapat meningkatkan motivasi kerja karyawan.Manfaat pemberian pengembangan kepada karyawan, secara langsung dapat memberikan motivasi kepada karyawan dalam menyelesaikan tugasnya. Menurut Nawawi (2005) pengembangan karir adalah dorongan (motivasi) untuk maju dalam bekerja di lingkungan suatu perusahaan.Dengan adanya program pengembangan karir, dapat lebih meningkatkan dorongan atau motivasi kepada karyawan untuk lebih berprestasi dan memberikan kontribusi yang maksimal kepada perusahaan. Hal ini terjadi dikarenakan bahwa motivasi seseorang akan timbul apabila pengembangan karir yang ada disebuah perusahaan sudah ada dan jelas untuk dapat dilaksanakan (Ekayadi, 2009). Penelitian Lisdiani (2017) mendapatkan hasil bahwa pengembangan karir berpengaruh signifikan terhadap motivasi kerja. Penelitian Anthony (2015) mendapatkan hasil bahwa pengembangan karir berpengaruh terhadap motivasi karyawan. Hasil penelitian Isyanto (2013) dan Nugroho \& Kunartinah (2012) menunjukkan bahwa pengembangan karir berpengaruh positif dan signifikan terhadap motivasi kerja. Upaya yang dapat dilakukan untuk mempertahankan atau meningkatkan motivasi kerja karyawan yaitu dengan cara 
memberikan kebijakan pengembangan karir yang adil dan sesuai. Semakin baik pengembangan karir karyawan maka semakin tinggi motivasi kerja karyawan.

Menurut Mathis \& Jackson (2001:82) salah satu faktor yang mempengaruhi kinerja adalah motivasi. Pemberian motivasi yang diberikan kepada karyawan akan meningkatkan semangat dan kinerja karyawan kepada perusahaan. Motivasi adalah pemberian daya penggerak yang menciptakan kegairahan kerja sesorang, agar mereka mau bekeja sama, bekerja efektif dan terintegrasi dengan segala daya upaya untuk mencapai kepuasan bahkan motivasi adalah alat terbaik untuk kinerja terbaik (Hasibuan 2012:95). Muogbo (2013) menyatakan bahwa pemberian motivasi bagi para pekerja dalam suatu organisasi dapat berpengaruh dengan signifikan terhadap kinerja para pekerja. Hasil penelitian Amalia (2016) menunjukkan bahwa motivasi kerja berpengaruh signifikan terhadap kinerja karyawan. Penelitian oleh Zameer et al. (2014) menemukan bahwa peran motivasi kerja sangat vital untuk meningkatkan kinerja karyawan. Pimpinan wajib memperhatikan karyawan, mengarahkan serta memotivasi untuk meningkatkan kinerja karyawan.

Hasil wawancara dengan pihak manajemen perusahaan menyatakan bahwa adanya permasalahan pada pengembangan karir, motivasi serta kinerja karyawan. Hal tersebut dapat dilihat dari indikasi permasalahan kurangnya informasi maupun minat mengenai pengembangan karir, kurang termotivasinya karyawan karena menganggap beban kerja yang diberikan tidak sesuai dengan gaji yang diterima, serta kurangnya keterampilan dalam melayani karyawan dan kurangnya penguasaan bahasa asing yang berakibat pada kinerja. Permasalahan lainnya dapat 
dilihat dari minimnya faktor kejujuran, kurang menghargai waktu, dan tidak melaksanakan tugas dengan semestinya, hal ini mengartikan masih rendahnya kinerja karyawan. Upaya yang dapat ditempuh perusahaan diantaranya adalah dengan memotivasi karyawan melalui penerapan pengembangan karir yang sesuai dengan kemampuan sehingga karyawan yang merasa termotivasi kinerjanya akan meningkat dalam perusahaan.

Penelitian yang dilakukan oleh Bianca dkk. (2013) menunjukkan hasil bahwa pengembangan karir karyawan secara langsung memberikan pengaruh positif terhadap kinerja karyawan. Hasil penelitian yang dilakukan oleh Caroline \& Susan (2014) menunjukkan bahwa kemajuan karir berpengaruh secara positif dan signifikan terhadap kinerja karyawan di Kenyata University. Hameed \& Waheed (2011) melakukan penelitian dan menemukan hasil bahwa pengembangan karyawan sangat mempengaruhi kinerja organisasi untuk kefektifan organisasi itu sendiri. Kakui (2016) dalam penelitiannya mengenai pengaruh pengembangan karir terhadap kinerja karyawan mendapatkan hasil bahwa pengembangan karir berpengaruh positif terhadap kinerja karyawan. Napitupulu (2017) mendapatkan hasil penelitian bahwa pengembangan karir berpengaruh positif terhadap kinerja karyawan. Hal ini menyatakan bahwa semakin baik pengembangan karir maka semakin baik kinerja karyawan.

$\mathrm{H}_{1}$ : Pengembangan karir berpengaruh positif terhadap kinerja karyawan.

Penelitian yang dilakukan oleh Sangkono (2013) mengenai pengaruh pengembangan karir terhadap motivasi mendapatkan hasil bahwa pengembangan karir memiliki pengaruh positif dan signifikan terhadap motivasi kerja karyawan. 
Oktavia dkk. (2014) melakukan penelitian mengenai pengaruh pengembangan karir tehadap motivasi dan mendapatkan hasil penelitian bahwa pengembangan karir berpengaruh signifikan terhadap motivasi. Li et al. (2014) mendapatkan hasil penelitian bahwa pengembangan karir berpengaruh positif terhadap motivasi karyawan. Hasil penelitian yang dilakukan oleh Bapiri \& Alizat (2015) menjukkan bahwa pengembangan karir berpengaruh positif dan signifikan terhadap motivasi kerja karyawan. Hasil yang sama diperoleh dari penelitian yang dilakukan oleh Pillay (2015) bahwa pengembangan karir berpengaruh positif terhadap motivasi karyawan. Hal ini berarti semakin baik pengembangan karir maka akan semakin tinggi motivasi kerja karyawan.

$\mathrm{H}_{2}$ : Pengembangan karir berpengaruh positif terhadap motivasi kerja karyawan.

Penelitian mengenai pengaruh motivasi terhadap kinerja karyawan dilakukan oleh Ridwan dkk. (2014) mendapatkan hasil bahwa adanya pengaruh yang signifikan secara simultan dari motivasi terhadap kinerja karyawan. Shahzadi et al. (2014) melakukan penelitian mengenai pengaruh motivasi terhadap kinerja dan mendapatkan hasil bahwa motivasi berpengaruh positif dan signifikan terhadap kinerja kayawan. Penelitian yang dilakukan oleh Maliah (2015) mengenai pengaruh motivasi terhadap kinerja pegawai mendapatkan hasil bahwa hubungan motivasi berpengaruh positif terhadap kinerja pegawai. Omollo (2015) bahwa motivasi berpengaruh positif dan signifikan terhadap kinerja.Hasil penelitian yang sama diperoleh dalam penelitian yang dilakukan Ibrahim (2017) bahwa motivasi karyawan berpengaruh positif terhadap kinerja karyawan. Maka 
dapat dinyatakan bahwa semakin tinggi motivasi karyawan maka semakin baik kinerja karwan, dan begitu pula sebaliknya.

$\mathrm{H}_{3}$ : Motivasi kerja karyawan berpengaruh positif terhadap kinerja karyawan.

Penelitian yang dilakukan oleh Akmal (2015) mengenai pengaruh pengembangan karir terhadap kinerja karyawan melalui mediasi motivasi kerja mendapatkan hasil bahwa motivasi kerja dapat memediasi pengaruh pengembangan karir terhadap kinerja karyawan. Hasil penelitian yang sama juga diperoleh oleh Ariesta (2016) bahwa motivasi kerja dapat memediasi pengaruh pegembangan karir terhadap kinerja karyawan. Hal ini berarti semakin tinggi motivasi kerja karyawan maka akan semakin baik pengembangan karir karyawan dan akan semakin baik pula kinerja karyawan.

$\mathrm{H}_{4}$ : Motivasi kerja karyawan memediasi pengaruh pengembangan karir terhadap kinerja karyawan.

\section{METODE PENELITIAN}

Lokasi penelitian ini adalah seluruh store brand havaianas yang berlokasi di Sunset Road, Discovery Shopping Mall, Mall Bali Galeria, Beachwalk, Seminyak, Batu Bolong, Sogo Discovery dan Nusadua, serta Ubud. Brand Havaianas dipilih sebagai lokasi penelitian karena belum ada yang melakukan penelitian di perusahaan tersebut mengenai sumber daya manusianya,serta dari hasil wawancara awal adanya indikasi terdapat masalah yang menyangkut pengembangan karir, kinerja karyawan, dan motivasi kerja karyawan.

Populasi dalam penelitian ini adalah seluruh karyawan PT. Kanmo Group pada Brand Havaianas yang berjumlah 64 orang. Metode penentuan sampel yang 
digunakan dalam penelitian ini adalah sampel jenuh atau sensus, dimana semua anggota populasi dijadikan sampel. Ini berarti jumlah sampel yang diteliti yaitu sebanyak 64 responden.

Tabel 1.

Populasi dan Sampel

\begin{tabular}{|c|c|c|c|c|c|c|c|}
\hline \multirow{2}{*}{ No } & \multirow{2}{*}{ Toko/Store } & \multicolumn{4}{|c|}{ Jabatan (orang) } & \multirow[b]{2}{*}{ ASM } & \multirow{2}{*}{$\begin{array}{l}\text { Populasi \& Sampel } \\
\text { (orang) }\end{array}$} \\
\hline & & SA & SSA & CA & SPV & & \\
\hline 1. & Sunset Road & 2 & 1 & 3 & & 1 & 7 \\
\hline 2. & Raya Seminyak & 2 & 1 & 3 & & & 6 \\
\hline 3. & Kayu Aya Seminyak & 2 & & 2 & 1 & & 5 \\
\hline 4. & Summer Shack Seminyak & 2 & 1 & 1 & 1 & & 5 \\
\hline 5. & Batu Bolong & 1 & & 2 & 1 & & 4 \\
\hline 6. & Mall Bali Galeria & 1 & 1 & 2 & & & 4 \\
\hline 7. & Discovery Mall & 3 & 1 & 1 & & & 5 \\
\hline 8. & Discovery Mall 2 & 2 & & 2 & 1 & & 5 \\
\hline 9. & Sogo Discovery Mall & 2 & & 1 & & & 3 \\
\hline 10. & Beachwalk Mall & & 1 & 2 & 1 & & 4 \\
\hline 11. & Sogo Nusa Dua & 2 & & & & & 2 \\
\hline 12. & Raya Ubud & 3 & 1 & 1 & & & 5 \\
\hline 13. & Raya Ubud 2 & & 1 & 3 & & & 4 \\
\hline \multirow[t]{2}{*}{14.} & Monkey Forest Ubud & 2 & & 2 & 1 & & 5 \\
\hline & Total & 24 & 8 & 25 & 6 & 1 & 64 \\
\hline
\end{tabular}

Sumber: Data diolah, 2018

Teknik analisis yang digunakan dalam penelitian ini adalah teknik analisis jalur. Analisis jalur merupakan perluasan dari analisis regresi linier berganda, denganmenerapkan variabel mediasi. Variabel mediasi merupakan variabel yang berperan memediasi hubungan antara suatu variabel dengan variabel lainnya. Analisis jalur hanya dapat digunakan apabila telah memenuhi asumsi-asumsi tertentu.

Persamaan Sub-struktural 1

$$
\mathrm{M}=\beta_{1} \mathrm{X}_{1}+\mathrm{e}_{1}
$$

Persamaan Sub-struktural 2

$$
\mathrm{Y}=\beta_{1} \mathrm{X}_{2}+\beta_{1} \mathrm{M}+\mathrm{e}_{2}
$$

Keterangan: 


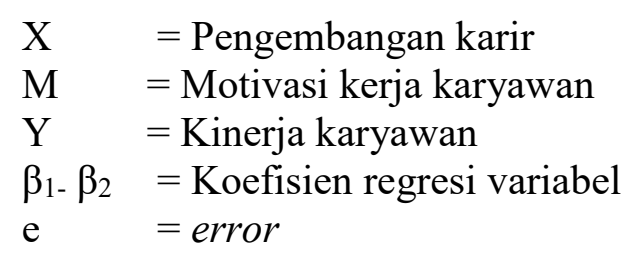

Pengujian hipotesis mediasi dapat dilakukan dengan Uji Sobel (Sobel Test). Uji sobel digunakan untuk menguji kekuatan pengaruh tidak langsung variabel pengembangan karir (X) ke variabel kinerja karyawan(Y) melalui variabel motivasi kerja karyawan(M). Pengaruh tidak langsung pengembangan karir (X) terhadap variabel kinerja karyawan (Y) melalui variabel motivasi kerja karyawan (M) dihitung dengan mengalikan koefisien jalur X terhadap $\mathrm{M}$ (a) dengan koefisien jalur M terhadap Y (b) atau ab. Standard error koefisien a dan b ditulis dengan $\mathrm{S}_{\mathrm{a}}$ dan $\mathrm{S}_{\mathrm{b}}$, besarnya standard error tidak langsung (indirect effect) $\mathrm{S}_{\mathrm{ab} 1}$ dihitung dengan rumus dibawah ini:

$$
\mathrm{S}_{\mathrm{ab}}=\sqrt{b^{2} S a^{2}+a^{2} S b^{2}+S a^{2} S b^{2}}
$$

Keterangan:

$\mathrm{Sa}=$ standar error koefisien $\mathrm{a}$

$\mathrm{Sb}=$ standar error koefisien $\mathrm{b}$

$\mathrm{b}=$ koefisien variabel mediasi

$\mathrm{a}=$ koefisien variabel bebas

Untuk menguji signifikansi pengaruh tidak langsung, maka dapat dilakukan dengan menghitung $\mathrm{t}$ dari koefisien ab dengan rumus sebagai berikut:

$$
\mathrm{Z}=\frac{a b}{S a b}
$$




\section{HASIL PENELITIAN DAN PEMBAHASAN}

Penelitian ini menggunakan data primer dari kuesioner yang dijawab oleh para responden yaitu sebanyak 64 orang karyawan PT. Kanmo Group pada brand Havaianas. Sebaran data karakteristik responden dikumpulkan untuk mengetahui profil responden penelitian. Berdasarkan hasil penelitian yang dilakukan, telah diketahui karakteristik responden meliputi jenis kelamin, usia, dan pendidikan terakhir. Data mengenai karakteristik responden disajikan pada Tabel 2.

Tabel 2.

Karakteristik Responden Penelitian

\begin{tabular}{|c|c|c|c|c|}
\hline No & Variabel & Klasifikasi & Jumlah & Persentase (\%) \\
\hline \multirow{2}{*}{1.} & \multirow{2}{*}{ Jenis Kelamin } & Pria & 25 & 39 \\
\hline & & Wanita & 39 & 61 \\
\hline \multirow{3}{*}{2.} & \multicolumn{2}{|c|}{ Jumlah } & 64 & 100 \\
\hline & \multirow{2}{*}{ Usia } & 18-27 tahun & 54 & 84 \\
\hline & & 28-37 tahun & 10 & 16 \\
\hline \multirow{3}{*}{3.} & \multicolumn{2}{|c|}{ Jumlah } & 64 & 100 \\
\hline & Pendidikan & SMA/ SMK & 62 & 97 \\
\hline & Terakhir & Diploma & 2 & 3 \\
\hline \multirow{4}{*}{4.} & \multicolumn{2}{|c|}{ Jumlah } & 64 & 100 \\
\hline & \multirow{3}{*}{ Masa Kerja } & $<1$ tahun & 45 & 70 \\
\hline & & 1-3 tahun & 19 & 30 \\
\hline & & & 64 & 100 \\
\hline \multirow{6}{*}{5.} & \multirow{6}{*}{ Jabatan } & Sales Advisor & 24 & 38 \\
\hline & & Senior Sales Advisor & 8 & 13 \\
\hline & & Cashier Advisor & 24 & 38 \\
\hline & & Supervisor & 6 & 9 \\
\hline & & Assistant Manager Store & 1 & 2 \\
\hline & & & 64 & 100 \\
\hline
\end{tabular}

Sumber: Data diolah, 2018

Tabel 2 menunjukkan bahwa untuk klasifikasi jenis kelamin responden cenderung didominasi oleh wanita yakni sebesar 61 persen bila dibandingkan dengan persentase responden yang berjenis kelamin pria hanya sebesar 39 persen. Tingkat usia dominan yang bekerja di perusahaan adalah dari usia 18-27 tahun, karena usia tersebut adalah usia yang tergolong produktif, kreatif, dan pekerja keras, sehingga dapat berkontribusi lebih baik untuk perusahaan. Tingkat 
pendidikan di perusahaan didominasi oleh karyawan dengan tingkat pendidikan SMA dengan presentase 97 persen, hal ini dikarenakan kualifikasi untuk pekerja yang akan ditempatkan di toko lebih membutuhkan pengalaman. Masa kerja karyawan di PT. Kanmo Group pada brand Havaianasberkisar dari 1-3 tahun, dimana masa kerja karyawan yang paling banyak adalah masa kerja kurang dari 1 tahun yang berjumlah 45 orang. Masa kerja pendek ini dikarenakan akuisisi brand Havaianas oleh PT. Kanmo Group baru berjalan 2 tahun dan masih melalukan ekspansi toko, maka masa kerja pendek ini mendominasi pada klasifikasi masa kerja. Klasifikasi selanjutnya yakni jabatan, yang dalam penelitian ini jabatan sales advisor dan cashier advisor memiliki jumlah karyawan yang sama yaitu 24 orang dengan presentase sebesar 38 persen.

Tabel 3.

Deskripsi Jawaban Responden terhadap Pengembangan Karir

\begin{tabular}{|c|c|c|c|c|c|c|c|}
\hline \multirow{2}{*}{ Pernyataan } & \multicolumn{5}{|c|}{ Frekuensi Jawaban Responden } & \multirow{2}{*}{$\begin{array}{c}\text { Rata- } \\
\text { rata }\end{array}$} & \multirow{2}{*}{ Ket. } \\
\hline & STS & TS & $\mathbf{N}$ & $\mathbf{S}$ & SS & & \\
\hline $\begin{array}{l}\text { Perusahaan memberikan perlakuan yang } \\
\text { adil pada setiap karyawan pada } \\
\text { pengembangan karir. }\end{array}$ & 0 & 1 & 25 & 29 & 9 & 3,72 & Baik \\
\hline $\begin{array}{l}\text { Atasan saya selalu mendukung } \\
\text { pengembangan karir karyawannya. }\end{array}$ & 0 & 3 & 18 & 31 & 12 & 3,81 & Baik \\
\hline $\begin{array}{l}\text { Saya yakin berkompeten dibidang } \\
\text { pekerjaan saya sekarang. }\end{array}$ & 0 & 2 & 27 & 23 & 12 & 3,70 & Baik \\
\hline $\begin{array}{l}\text { Saya merasa memiliki cukup informasi } \\
\text { mengenai promosi jabatan yang ada di } \\
\text { perusahaan. }\end{array}$ & 27 & 26 & 8 & 3 & 0 & 1,80 & $\begin{array}{l}\text { Sangat } \\
\text { buruk }\end{array}$ \\
\hline $\begin{array}{l}\text { Saya berminat untuk dipromosikan } \\
\text { atasan. }\end{array}$ & 0 & 0 & 5 & 27 & 32 & 4,42 & $\begin{array}{c}\text { Sangat } \\
\text { baik }\end{array}$ \\
\hline \multicolumn{6}{|c|}{ Rata-rata keseluruhan variabel pengembangan karir } & 3,49 & Baik \\
\hline
\end{tabular}

Tabel 3 menunjukkan bahwa rata-rata keseluruhan deskripsi jawaban responden pada variabel pengembangan karir yaitu sebesar 3,49 yang berada dalam kriteria baik. Hal ini berarti bahwa para karyawan menganggap bahwa adanya kesempatan pengembangan karir yang baik di PT. Kanmo Group pada 
brand Havaianas. Indikator dengan nilai tertinggi ditunjukkan pada pernyataan nomor 5 yakni“saya berminat untuk dipromosikan atasan" dengan skor rata-rata sebesar 4,42 yang termasuk dalam kategori sangat baik. Hasil ini dapat berarti bahwa para karyawan sangat berminat untuk mendapatkan promosi jabatan dari atasan untuk mengembangkan karirnya. Sementara itu, indikator dengan nilai terendah terdapat pada pernyataan nomor 4 yaitu "saya merasa memiliki cukup informasi mengenai promosi jabatan yang ada di perusahaan" dengan skor ratarata sebesar 1,80 yang termasuk dalam kategori sangat buruk. Hal tersebut dapat berarti para karyawan merasa sangat tidak memperoleh akses yang baik pada informasi mengenai peluang-peluang pengembangan karir

Tabel 4.

Deskripsi Jawaban Responden terhadap Motivasi Kerja Karyawan

\begin{tabular}{|c|c|c|c|c|c|c|c|}
\hline \multirow{2}{*}{ Pernyataan } & \multicolumn{5}{|c|}{ Frekuensi Jawaban Responden } & \multirow{2}{*}{$\begin{array}{c}\text { Rata- } \\
\text { rata }\end{array}$} & \multirow{2}{*}{ Ket. } \\
\hline & STS & TS & $\mathbf{N}$ & $\mathbf{S}$ & SS & & \\
\hline $\begin{array}{l}\text { Saya selalu antusias untuk segera } \\
\text { menyelesaikan pekerjaan. }\end{array}$ & 26 & 32 & 4 & 2 & 0 & 1,72 & $\begin{array}{l}\text { Sangat } \\
\text { rendah }\end{array}$ \\
\hline $\begin{array}{l}\text { Saya memiliki potensi dalam } \\
\text { pengembangan karir di perusahaan. }\end{array}$ & 0 & 0 & 0 & 24 & 40 & 4,63 & $\begin{array}{l}\text { Sangat } \\
\text { tinggi }\end{array}$ \\
\hline $\begin{array}{l}\text { Saya selalu menyelesaikan pekerjaan } \\
\text { dengan tanggung jawab. }\end{array}$ & 6 & 28 & 20 & 10 & 12 & 3,47 & Tinggi \\
\hline $\begin{array}{l}\text { Saya memanfaatkan kompetensi yang } \\
\text { saya miliki untuk mencapai hasil yang } \\
\text { terbaik dalam menyelesaikan } \\
\text { pekerjaan. }\end{array}$ & 0 & 4 & 28 & 23 & 9 & 3,58 & Tinggi \\
\hline $\begin{array}{l}\text { Saya dapat menjalin hubungan kerja } \\
\text { yang baik dengan sesama rekan kerja. }\end{array}$ & 0 & 4 & 29 & 26 & 5 & 3,50 & Tinggi \\
\hline \multicolumn{6}{|c|}{ Rata-rata keseluruhan variabel motivasi kerja karyawan } & 3,13 & Sedang \\
\hline
\end{tabular}

Sumber: Data diolah, 2018

Tabel 4 menunjukkan bahwa rata-rata keseluruhan deskripsi jawaban responden pada variabel motivasi kerja karyawan yaitu sebesar 3,13 yang berada dalam kriteria sedang. Hal ini berarti bahwa para karyawan PT. Kanmo Group pada brand Havaianas memiliki motivasi yang sedang dalam bekerja. Indikator dengan nilai tertinggi ditunjukkan pada pernyataan nomor 2 yakni“saya memiliki 
potensi dalam pengembangan karir di perusahaan.." dengan skor rata-rata sebesar 4,63 yang masuk dalam kategori sangat tinggi. Hasil ini dapat berarti bahwa motivasi kerja para karyawan PT. Kanmo Group pada brand Havaianas sangat terbentuk dari keyakinan karyawan akan potensi yang dimiliki sehingga dapat digunakan untuk pengembangan karir ke jenjang yang lebih tinggi. Sementara itu, indikator dengan nilai terendah terdapat pada pernyataan nomor 1 yaitu "saya selalu antusias untuk segera menyelesaikan pekerjaan." dengan skor rata-rata sebesar 1,72 yang termasuk dalam kategori sangat rendah. Hal tersebut dapat berarti sangat rendahnya tingkat motivasi kerja melalui faktor pendorong yang timbul dari dalam diri masing-masing karyawan.

Tabel 5.

Deskripsi Jawaban Responden terhadap Kinerja Karyawan

\begin{tabular}{|c|c|c|c|c|c|c|c|}
\hline \multirow{2}{*}{ Pernyataan } & \multicolumn{5}{|c|}{$\begin{array}{l}\text { Frekuensi Jawaban } \\
\text { Responden }\end{array}$} & \multirow{2}{*}{$\begin{array}{l}\text { Rata- } \\
\text { rata }\end{array}$} & \multirow{2}{*}{ Ket. } \\
\hline & STS & TS & $\mathbf{N}$ & $\mathbf{S}$ & SS & & \\
\hline $\begin{array}{l}\text { Memiliki inisiatif dalam } \\
\text { menyelesaikan permasalahan. }\end{array}$ & 0 & 4 & 18 & 30 & 12 & 3,78 & Baik \\
\hline $\begin{array}{l}\text { Bekerja sesuai prosedur dan jadwal } \\
\text { yang ditetapkan perusahaan. }\end{array}$ & 11 & 25 & 17 & 7 & 4 & 2,50 & $\begin{array}{l}\text { Tidak } \\
\text { Baik }\end{array}$ \\
\hline $\begin{array}{l}\text { Kemampuan yang mendalam dalam } \\
\text { menyelesaikan setiap pekerjaan yang } \\
\text { diberikan oleh perusahaan. }\end{array}$ & 0 & 3 & 30 & 25 & 6 & 3,53 & Baik \\
\hline $\begin{array}{l}\text { Sangat bersungguh-sungguh di dalam } \\
\text { menerima tugas yang diberikan } \\
\text { perusahaan. }\end{array}$ & 0 & 4 & 27 & 25 & 8 & 3,58 & Baik \\
\hline $\begin{array}{l}\text { Memiliki kepedulian yang tinggi } \\
\text { untuk kemajuan perusahaan. }\end{array}$ & 26 & 30 & 5 & 3 & 0 & 1,77 & $\begin{array}{l}\text { Sangat } \\
\text { buruk }\end{array}$ \\
\hline $\begin{array}{l}\text { Hasil kerja yang sudah dilakukan } \\
\text { merupakan hasil terbaik yang bisa } \\
\text { diberikan. }\end{array}$ & 0 & 0 & 7 & 32 & 25 & 4,28 & $\begin{array}{c}\text { Sangat } \\
\text { Baik }\end{array}$ \\
\hline \multicolumn{6}{|c|}{ Rata-rata keseluruhan variabel kinerja karyawan } & 3,24 & Sedang \\
\hline
\end{tabular}
Sumber: Data diolah, 2018

Tabel 5 menunjukkan bahwa rata-rata keseluruhan deskripsi jawaban responden pada variabel kinerja karyawan yaitu sebesar 3,24 yang berada dalam 
kriteria sedang. Hal ini berarti bahwa para karyawan PT. Kanmo Group pada brand Havaianas memiliki kinerja yang cukup kuat. Interpretasi tersebut diperkuat dengan pernyataan nomor 6 yakni "hasil kerja yang sudah dilakukan merupakan hasil terbaik yang bisa diberikan" sebagai indikator dengan nilai skor rata-rata tertinggi sebesar 4,28 yang termasuk dalam kategori sangat baik, sehingga dapat dikatakan para karyawan PT. Kanmo Group pada brand Havaianas menganggap bahwa lemah kuatnya kinerja sangat tergantung dari kualitas hasil kerja yang telah dilakukan yaitu seberapa baik penyelesaiannya. Sementara itu, indikator dengan nilai terendah ditunjukkan pada pernyataan nomor 5 yakni“memiliki kepedulian yang tinggi untuk kemajuan perusahaan" dengan skor rata-rata sebesar 1,77 yang termasuk dalam kategori sangat buruk. Hasil ini dapat berarti bahwa para karyawan PT. Kanmo Group pada brand Havaianas cenderung tidak peduli mengenai hal-hal yang menyangkut kemajuan perusahaan.

Berdasarkan hasil pengolahan data, hasil analisis jalur dapat dijelaskan sebagai berikut.

Tabel 6

Hasil Analisis Jalur Persamaan Regresi 1

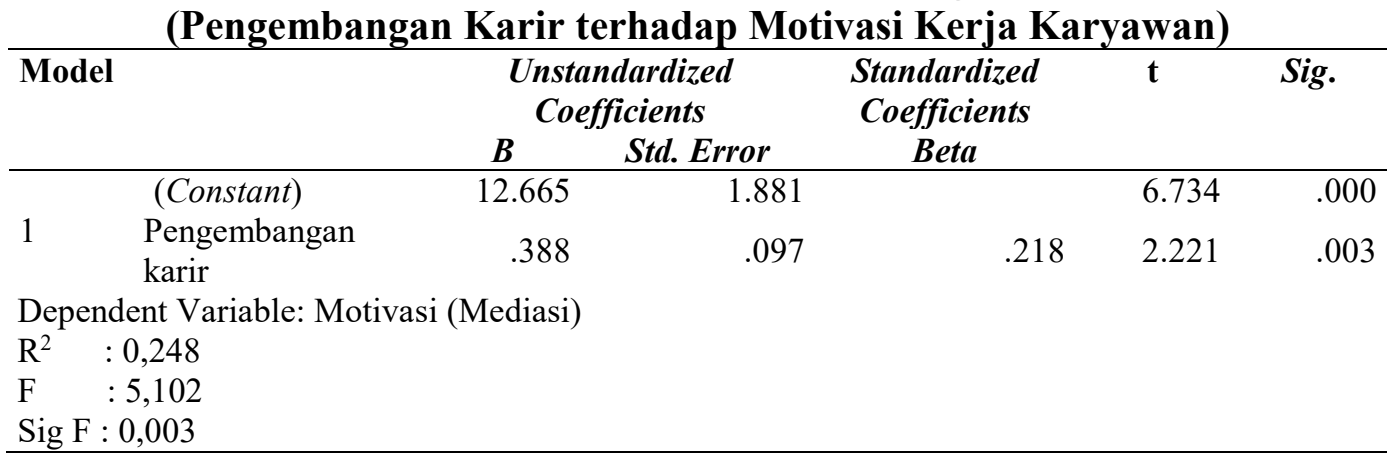

Sumber: Data diolah, 2018

Berdasarkan hasil analisis pengaruh pengembangan karir terhadap kinerja karyawan, diperoleh nilai koefisien beta sebesar 0,272 yang berarti adanya arah 
yang positif serta nilai signifikansi sebesar 0,021 yang kurang dari 0,05 berarti adanya pengaruh yang signifikan. Hasil ini mengindikasikan bahwa $\mathrm{H}_{0}$ ditolak dan $\mathrm{H}_{1}$ diterima sehingga pengembangan karir berpengaruh positif dan signifikan terhadap kinerja karyawan.

Tabel 7.

Hasil Analisis Jalur Persamaan Regresi 2 (Pengembangan Karir dan Motivasi Kerja Karyawan terhadap Kinerja Karyawan)

\begin{tabular}{llrrrrr}
\hline Model & & \multicolumn{2}{c}{$\begin{array}{c}\text { Unstandardized } \\
\text { Coefficients }\end{array}$} & $\begin{array}{c}\text { Standardized } \\
\text { Coefficients } \\
\text { Beta }\end{array}$ & t & Sig. \\
& & B & Std. Error & Beta & \\
\hline \multirow{3}{*}{1} & (Constant) & 7.445 & 2.807 & & 2.652 & .010 \\
& Pengembangan karir & .294 & .124 & .272 & 2.368 & .021 \\
& Motivasi Kerja & .310 & .094 & .343 & 2.982 & .004
\end{tabular}

Dependent Variable: Kinerja Karyawan

$\mathrm{R}^{2} \quad: 0,465$

F : : 9,231

Sig F : 0,000

Sumber: Data diolah, 2018

Perhitungan determinasi total $\left(\mathrm{R}^{2} \mathrm{~m}\right)$ :

$$
\begin{aligned}
& \mathrm{ei}=\sqrt{1-\mathrm{Ri}^{2}} \\
& \mathrm{e}_{1}=\sqrt{1-\mathrm{R}_{1}{ }^{2}}=\sqrt{1-0,248}=0,867 \\
& \mathrm{e}_{2}=\sqrt{1-\mathrm{R}_{2}{ }^{2}}=\sqrt{1-0,465}=0,731
\end{aligned}
$$

Berdasarkan perhitungan nilai standar eror, diperoleh hasil $\mathrm{e}_{1}$ (standar eror variabel motivasi kerja karyawan) sebesar 0,867 dan $\mathrm{e}_{2}$ (standar eror variabel kinerja karyawan)sebesar 0,731. Perhitungan koefisien determinasi total adalah sebagai berikut:

$$
\begin{aligned}
\mathrm{R}^{2} \mathrm{~m} & =1-\left(\mathrm{e}_{1}\right)^{2}\left(\mathrm{e}_{2}\right)^{2} \ldots \ldots \ldots \ldots \\
& =1-(0,867)^{2}(0,731)^{2} \\
& =0,599
\end{aligned}
$$


Nilai determinasi total sebesar 0,599 mempunyai arti bahwa variasi kinerja karyawan dipengaruhi oleh variasi pengembangan karir dan motivasi kerja karyawan, dan sisanya sebesar 40,1 persen dipengaruhi oleh variabel lain yang tidak dianalisis ke dalam model penelitian ini.

Berdasarkan hasil analisis pengaruh pengembangan karir terhadap kinerja karyawan, sebesar 0,272 yang berarti adanya arah yang positif serta nilai signifikansi sebesar 0,021 yang kurang dari 0,05 berarti adanya pengaruh yang signifikan. Hasil ini mengindikasikan bahwa $\mathrm{H}_{0}$ ditolak dan $\mathrm{H}_{1}$ diterima sehingga pengembangan karir berpengaruh positif dan signifikan terhadap kinerja karyawan.

Berdasarkan hasil analisis pengaruh pengembangan karir terhadap motivasi kerja karyawan sebesar 0,218 yang berarti adanya arah yang positif serta nilai signifikansi sebesar 0,003 yang kurang dari 0,05 berarti adanya pengaruh yang signifikan. Hasil ini mengindikasikan bahwa $\mathrm{H}_{0}$ ditolak dan $\mathrm{H}_{2}$ diterima sehingga pengembangan karir berpengaruh positif dan signifikan terhadap motivasi kerja karyawan.

Berdasarkan hasil analisis pengaruh motivasi kerja karyawan terhadap kinerja karyawan sebesar 0,343 dan nilai signifikansi sebesar 0,004 lebih kecil dari 0,05 berarti adanya pengaruh yang signifikan. Hasil ini mengindikasikan bahwa motivasi kerja karyawan berpengaruh positif dan signifikan terhadap kinerja karyawan. 
Pengujian hipotesis pengaruh langsung, pengaruh tidak langsung, serta pengaruh total antar variabel. Pengujian variabel mediasi dirangkum dalam Tabel 8.

Tabel 8.

Pengaruh Langsung dan Pengaruh Tidak Langsung serta Pengaruh Total Pengembangan karir (X), Motivasi kerja karyawan (M), dan Kinerja karyawan (Y)

\begin{tabular}{cccc}
\hline $\begin{array}{c}\text { Pengaruh } \\
\text { Variabel }\end{array}$ & $\begin{array}{c}\text { Pengaruh } \\
\text { Langsung }\end{array}$ & $\begin{array}{c}\text { Pengaruh Tidak Langsung Melalui } \\
\text { Motivasi kerja karyawan } \\
\left(\mathbf{\beta}_{\mathbf{2}} \mathbf{\boldsymbol { \beta } _ { \mathbf { 3 } } )}\right.\end{array}$ & $\begin{array}{c}\text { Pengaruh } \\
\text { Total }\end{array}$ \\
\hline $\mathrm{X} \rightarrow \mathrm{Y}$ & 0,272 & 0,075 & 0,347 \\
$\mathrm{X} \rightarrow \mathrm{M}$ & 0,218 & - & 0,218 \\
$\mathrm{M} \rightarrow \mathrm{Y}$ & 0,343 & - & 0,343 \\
\hline
\end{tabular}
Sumber: Data Diolah, 2018

Berdasarkan Tabel 8 dapat dilihat bahwa pengembangan karir memiliki pengaruh langsung terhadap kinerja karyawan dan pengaruh tidak langsung melalui motivasi kerja karyawan. Besarnya koefisien pengaruh tidak langsung dapat dihitung dengan mengalikan koefisien jalur dari pengembangan karir ke motivasi kerja karyawan dengan koefisien jalur dari motivasi kerja karyawan ke kinerja karyawan sebesar $0,218 \times 0,343=0,075$. Hasil koefisien pengaruh tidak langsung lebih kecil dibandingkan pengaruh langsung $(0,075<0,272)$, sehingga dapat dikatakan bahwa variabel motivasi kerja karyawan adalah sebagai variabel mediasi dalam memediasi pengaruh variabel pengembangan karir tehadap variabel kinerja karyawan.

Pengujian signifikansi dari hubungan tidak langsung antara variabel independen dengan variabel dependen yang dimediasi oleh variabel mediasi dapat menggunakan alat analisis yang disebut uji Sobel. Uji Sobel dirumuskan dengan persamaan berikut: 
$\mathrm{z}=\frac{\mathrm{ab}}{\sqrt{\mathrm{b}^{2} \mathrm{~S}_{\mathrm{a}}^{2}+\mathrm{a}^{2} \mathrm{Sb}^{2}+\mathrm{S}_{\mathrm{a}}^{2} \mathrm{Sb}^{2}}}$

Keterangan:

$\mathrm{S}_{\mathrm{a}}=$ standar eror keofisien a

$\mathrm{S}_{\mathrm{b}}=$ standar eror keofisien $\mathrm{b}$

$\mathrm{A}=$ koefisien jalur $\mathrm{X}$ terhadap $\mathrm{M}$

$\mathrm{B}=$ koefisien jalur $\mathrm{M}$ terhadap $\mathrm{Y}$

$\mathrm{ab}=$ hasil kali koefisien jalur $\mathrm{X}$ terhadap koefisien jalur $\mathrm{M}(\mathrm{a})$ dengan jalur M terhadap Y (b)

Setelah mendapatkan hasil z hitung, selanjutnya dibandingkan dengan nilai z tabel yaitu 1,999. Jika nilai $\mathrm{z}$ hitung lebih besar dari $\mathrm{z}$ tabel, maka kesimpulannya adalah terjadi pengaruh mediasi secara signifikan. Perhitungan Uji Sobel untuk pengaruh tidak langsung antara pengembangan karir terhadap kinerja karyawan melalui motivasi kerja karyawan dihitung sebagai berikut:

$\mathrm{z}=\frac{\mathrm{ab}}{\sqrt{\mathrm{b}^{2} \mathrm{~S}_{\mathrm{a}}^{2}+\mathrm{a}^{2} \mathrm{Sb}^{2}+\mathrm{S}_{\mathrm{a}}^{2} \mathrm{Sb}^{2}}}$

$\mathrm{z}=\frac{0,388 \times 0,310}{\sqrt{0,310^{2} \times 0,097^{2}+0,388^{2} \times 0,094^{2}+0,097^{2} \times 0,094^{2}}}$

$\mathrm{z}=\frac{0,12028}{0,04814}=2,499$

Berdasarkan perhitungan, didapatkan nilai z hitung sebesar 2,499 yang artinya lebih besar dari nilai z tabel $(2,499>1,999)$. Hasil ini memiliki arti bahwa motivasi kerja karyawan mampu memediasi pengaruh pengembangan karir terhadap kinerja karyawan. Oleh karena itu, $\mathrm{H}_{4}$ yang menyatakan bahwa motivasi kerja karyawan memediasi pengaruh pengembangan karir terhadap kinerja karyawan diterima. 
Berdasarkan hasil pengujian hipotesis pertama, diperoleh beta sebesar 0,272 dengan signifikansi sebesar 0,021 . Nilai koefisien beta yang memiliki arah positif serta nilai signifikansi yang lebih besar dari tingkat probabilitas 0,05 mengartikan bahwa $\mathrm{H}_{1}$ diterima, maka pengembangan karir berpengaruh positif dan signifikan terhadap kinerja karyawan. Hasil rata-rata keseluruhan deskripsi responden terhadap pengembangan karir berada pada kualifikasi baik. Hal ini dapat dilihat dari tingginya minat karyawan untuk dipromosikan serta atasan yang selalu mendukung pengembangan karir kayawan yang akan mempengaruhi kinerja karyawan.

Hasil penelitian ini memperkuat beberapa penelitian sebelumnya yang telah membuktikan bahwa pengembangan karir berpengaruh positif dan signifikan terhadap kinerja karyawan seperti yang dilakukan Caroline \& Susan (2014) yang melakukan penelitian di Kenyata University memperoleh hasil bahwa pengembangan karir karyawan secara langsung memberikan pengaruh positif terhadap kinerja karyawan. Begitu juga penelitian yang dilakukan Bianca dkk. (2013), Hameed \& Waheed (2011), Kakui (2016), serta Napitupulu (2017).

Berdasarkan hasil pengujian hipotesis kedua, diperoleh beta sebesar 0,218 dengan signifikansi sebesar 0,003 . Nilai koefisien beta yang memiliki arah positif serta nilai signifikansi yang lebih besar dari tingkat probabilitas 0,05 mengartikan bahwa $\mathrm{H}_{2}$ diterima, maka pengembangan karir berpengaruh positif dan signifikan terhadap motivasi kerja karyawan. Hasil rata-rata keseluruhan deskripsi responden terhadap motivasi kerja berada pada kualifikasi sedang. Meningkatnya motivasi karyawan dapat dilihat dari atasan yang selalu mendukung pengembangan karir 
karyawannya dan minat karyawan yang tinggi untuk di promosikan sehingga karyawan merasa memiliki potensi dalam pengembangan karir di perusahaan.

Hasil penelitian ini sejalan dengan beberapa penelitian sebelumnya yang telah membuktikan bahwa pengembangan karir berpengaruh positif dan signifikan terhadap motivasi kerja karyawan seperti yang dilakukan Sangkono (2013) yang mendapatkan hasil bahwa pengembangan karir memiliki pengaruh positif dan signifikan terhadap motivasi kerja karyawan. Begitu juga penelitian yang dilakukan Oktavia dkk. (2014), Li et al. (2014), Bapiri \& Alizat (2015), serta Pillay (2015).

Berdasarkan hasil pengujian hipotesis ketiga, diperoleh beta sebesar 0,343 dengan signifikansi sebesar 0,004 . Nilai koefisien beta yang memiliki arah positif serta nilai signifikansi yang lebih besar dari tingkat probabilitas 0,05 mengartikan bahwa $\mathrm{H}_{3}$ diterima maka motivasi kerja karyawan berpengaruh positif dan signifikan terhadap kinerja karyawan. Hasil rata-rata keseluruhan deskripsi responden terhadap motivasi kerja berada pada kualifikasi sedang. Hal ini dapat dilihat dari adanya rasa tanggung jawab serta karyawan memanfaatkan kompetensinya untuk mendapatkan hasil terbaik dalam menyelesaikan pekerjaan serta adanya hubungan kerja yang baik dengan sesama rekan kerja yang akan berdampak pada kinerja karyawan.

Hasil penelitian ini memperkuat beberapa penelitian sebelumnya yang telah membuktikan bahwa motivasi kerja karyawan berpengaruh positif dan signifikan terhadap kinerja karyawan seperti penelitian yang dilakukan Ridwan dkk. (2014) yang mendapatkan hasil bahwa adanya pengaruh yang signifikan secara simultan 
dari motivasi terhadap kinerja karyawan. Hasil yang sama juga ditemukan oleh Shahzadi et al. (2014), Maliah (2015), Omollo (2015), serta Ibrahim (2017).

Berdasarkan pengujian dengan uji Sobel menunjukkan bahwa nilai z hitung sebesar 2,499 yang lebih besar dari z tabel yaitu 1,999 sehingga $\mathrm{H}_{4}$ diterima. Hasil ini mengartikan bahwa motivasi kerja karyawan mampu memediasi pengaruh pengembangan karir terhadap kinerja karyawan. Oleh karena itu, dapat diinterpretasikan bahwa pengembangan karir karyawan PT. Kanmo Group pada brand Havaianas yang baik akan berdampak pada tingginya tingkat motivasi kerja karyawan sehingga kinerja karyawan PT. Kanmo Group pada brand Havaianas akan semakin kuat. Hasil penelitian ini sesuai dengan penelitian sebelumnya yang dilakukan oleh Akmal (2015) yang mendapatkan hasil bahwa motivasi kerja dapat memediasi pengaruh pengembangan karir terhadap kinerja karyawan. Begitu juga penelitian yang dilakukan Ariesta (2016) yang memperoleh kesimpulan bahwa motivasi kerja dapat memediasi pengaruh pegembangan karir terhadap kinerja karyawan.

Implikasi penelitian ini menekankan pada manfaat nyata dari hasil penelitian yang telah dilakukan. Penelitian ini menggunakan pendekatan pengembangan karir dan motivasi kerja karyawan yang merupakan pengaruh langsung dari kinerja karyawan. Pengembangan karir terbukti secara positif mempengaruhi kinerja karyawan, oleh karena itu penting bagi manajemen PT. Kanmo Group pada brand Havaianas untuk selalu memperhatikan indikatorindikator pengembangan karir para karyawan di perusahaan. Hal tersebut demi membuat kinerja karyawan dapat lebih kuat dari sebelumnya. Pengembangan 
karir terbukti secara positif mempengaruhi motivasi kerja karyawan, sehingga kembali lagi pentingnya pemberian kesempatan pengembangan karir agar karyawan PT. Kanmo Group merasa lebih termotivasi dalam bekerja.

Motivasi kerja karyawan terbukti secara positif mempengaruhi kinerja karyawan, oleh karena itu perhatian terhadap faktor-faktor yang mempengaruhi motivasi kerja karyawan hendaknya ditingkatkan. Ketika karyawan PT. Kanmo Group pada brand Havaianas memiliki motivasi yang tinggi dalam bekerja, maka mereka akan memberikan lebih banyak upaya dalam bekerja demi meraih tujuan bersama, sehingga kinerja karyawan akan semakin kuat. Keterkaitan antara pengembangan karir, motivasi kerja karyawan, dan kinerja karyawan bisa dijadikan pertimbangan bagi perusahaan lainnya dalam keputusan menyangkut sumber daya manusia demi terciptanya operasional perusahaan yang lebih baik.

\section{SIMPULAN DAN SARAN}

Berdasarkan pada hasil serta pembahasan penelitian yang telah dipaparkan, maka dapat disimpulkan bahwa pengembangan karir berpengaruh secara positif dan signifikan terhadap kinerja karyawan. Hasil ini menunjukkan bahwa adanya kesempatan pengembangan karir yang baik akan memperkuat kinerja karyawan PT. Kanmo Group pada brand Havaianas. Sebaliknya, jika kesempatan pengembangan karir tidak baik maka kinerja karyawan karyawan PT. Kanmo Group Bali pada brand Havaianas akan semakin tidak kuat.

Pengembangan karir berpengaruh secara positif dan signifikan terhadap motivasi kerja karyawan. Hasil ini menunjukkan bahwa apabila pengembangan karir semakin baik maka tingkat motivasi kerja yang dimiliki para karyawan PT. 
Kanmo Group pada brand Havaianas akan semakin tinggi. Sebaliknya, jika pengembangan karir tidak baik maka motivasi kerja para karyawan PT. Kanmo Group pada brand Havaianas akan semakin rendah.

Motivasi kerja karyawan berpengaruh secara positif dan signifikan terhadap kinerja karyawan. Hasil ini menunjukkan bahwa apabila tingkat motivasi kerja karyawan tinggi maka kinerja karyawan PT. Kanmo Group pada brand Havaianas akan semakin kuat. Sebaliknya, jika tingkat motivasi kerja karyawan rendah maka tingkat kinerja karyawan para karyawan PT. Kanmo Group pada brand Havaianas akan semakin tidak kuat. Motivasi kerja karyawan memediasi pengaruh pengembangan karir terhadap kinerja karyawan. Hasil ini menunjukkan bahwa pengembangan karir karyawan PT. Kanmo Group pada brand Havaianas yang baik akan berdampak pada tingginya tingkat motivasi kerja karyawan sehingga kinerja karyawan PT. Kanmo Group pada brand Havaianas akan semakin kuat.

Berdasarkan hasil analisis, pembahasan, dan simpulan, maka saran yang dapat diberikan adalah salah satu hal yang hendaknya menjadi perhatian khusus manajemen PT. Kanmo Group pada brand Havaianas saat ini adalah akses informasi karyawan mengenai kesempatan pengembangan karir, mengingat deskripsi jawaban responden mengenai pengembangan karir pada pernyataan nomor 4 yaitu "saya merasa memiliki cukup informasi mengenai promosi jabatan yang ada di perusahaan" memperoleh skor rata-rata terendah yang termasuk dalam kategori sangat tidak baik. Kesempatan pengembangan karir penting dalam hal peningkatan motivasi karyawan dalam bekerja dan kualitas kinerja itu sendiri, sehingga pemberian informasi mengenai promosi jabatan sebagai salah satu 
indikator pengembangan karir hendaknya dilakukan secara transparan dan berkala.

Deskripsi jawaban responden mengenai motivasi kerja karyawan pada pernyataan nomor 1 yaitu "saya memiliki motivasi kerja yang timbul dari dalam diri sendiri untuk mencapai hasil yang diharapkan" memperoleh skor rata-rata paling rendah dibandingkan pernyataan lainnya dengan skor sebesar 1,72 yang termasuk dalam kategori sangat rendah. Hal tersebut dapat menjadi pertimbangan manajemen PT. Kanmo Group pada brand Havaianas untuk meningkatkan faktor intrinsik motivasi kerja yakni faktor-faktor pendorong yang timbul dari dalam diri masing-masing karyawan berupa pekerjaan itu sendiri, kemajuan, tanggung jawab, pengakuan, serta pencapaian.

Mengingat deskripsi jawaban responden mengenai kinerja karyawan pada pernyataan nomor 5 yaitu“memiliki kepedulian yang tinggi untuk kemajuan perusahaan" memperoleh skor rata-rata paling kecil sebesar 1,77 yang termasuk dalam kategori sangat tidak kuat, maka manajemen PT. Kanmo Group pada brand Havaianas sebaiknya mengevaluasi kembali hal-hal yang menyebabkan rendahnya tingkat kepedulian karyawan menyangkut kemajuan perusahaan. Para karyawan yang peduli dengan kemajuan perusahaan akan lebih termotivasi dalam bekerja sehingga membentuk kinerja yang lebih kuat.

\section{REFERENSI}

Akmal, Umar. (2015). The effect of motivation and career development againt employees performance and job satisvaction of The Governor Office Office South Sulawesi Province, Indonesia. International Joournal of Management Sciences. 5(9): 628-638. 
Amalia, S., \& Fakhri, M. (2016). Pengaruh motivasi kerja terhadap kinerja karyawan pada PT. Gramedia Asri Media Cabang Emerald Bintaro. Jurnal Computech \& Bisnis. 10(2): 119-127.

Anthony, P. J., \& Weide, J. (2015). Motivation and career-development training programs: Use of regulatory focus to determine program effectiveness. Higher Learning Research Communications. 5(2): 24-33.

Ariesta Angga Dewi, Ni Luh Putu. (2016). Pengaruh pengembangan karir terhadap kinerja karyawan melalui mediasi motivasi kerja pada Karya Mas Art Gallery. E-Jurnal Manajemen Unud. 5(9): 5494-5523.

Bapiri, S. \& Alizat, R.N. (2015). Evaluation of the effect of career development on accupational motivation in employees of the Sepah Bank in Kermanshah Country. GMP Review. 18(1): 633-642.

Bianca, A., Putiri, B., Katili, Shanti K., \& Anggraeni. (2013). Pengaruh motivasi, pengembangan karir, dan kepuasan kerja terhadap kinerja karyawan dengan metode structural modelling. Jurnal Teknik Industri. 1(4): 334340 .

Ekayadi, S. (2009). Pengaruh motivasi dan pengembangan karir terhadap kepuasan kerja karyawan pada PT. Rimbajatiraya Citrakarya. Tesis Universitas Gunadarma.

Febriansyah, R. E. (2016). Pengaruh pengembangan karir terhadap kinerja karyawan melalui kepuasan karir dan komitmen karir sebagai variabel intervening. Prosiding Seminar Nasional Ekonomi dan bisnis \& Call For Paper FEB UMSIDA.

Hameed, A., \& Waheed, A. (2011). Employee development and its affect on employee performance a conceptual framework. International Journal Of Business And Social Science. 2(1): 224-230.

Hasibuan, Malayu S.P. (2012). Manajemen Sumber Daya Manusia Edisi Revisi. Jakarta: Bumi Aksara.

Ibrahim, A.A. (2017). The effect of motivation on employee performance: case study in Hormuud Company in Mogadishu Somalia. International Journal of Development Research. 07(11):17009 - 17016.

Isyanto, Puji. (2013). Pengaruh perkembangan karir terhadap motivasi karyawan. Jurnal Manajemen. 10(3). 15-24.

Kakui, I.M., \& Gachunga, H. (2016). Effects of career development on employee performance in the public sector: a case of National Cereals And Produce Board. The Strategic Journal of Business and Change Management. 3(19): 308-342. 
Li, K. S., Canon, T., \& Anthony, W. (2014). The impact of career development on employee commitment of Part-Time Faculty (PTF) in Hong Kong's Continuing Professional Development (CPD) Sector. British Journal of Education, Society \& Behavioural Science. 4(1): 52-73

Lisdiani, V. (2017). Pengaruh pengembangan karir terhadap kepuasan kerja karyawan melalui motivasi kerja sebagai variabel intervening (studi kasus pada Hotel Grasia Semarang). Diponegoro Journal Of Social And Political Science. 6(4): 1-8.

Maliah, M. (2015). Pengaruh motivasi terhadap kinerja pegawai pada PT. PLN (Persero) Rayon Pangkalan Balai. Jurnal Media Wahana Ekonomika. 12(2): $31-39$.

Marwansyah. (2014). Manajemen Sumber Daya Manusia. Edisi kedua. Bandung: ALFABETA.

Mathis. L. R \& Jackson. H. J. (2001). Manajemen Sumber Daya Manusia. Jakarta : Buku kedua.

Muogbo. (2013). The impact of employee motivation on organisational performance (a study of some selected firms in Anambra State Nigeria). The International Journal of Engineering and Science. 2(7): 70-80.

Napitupulu, S. (2017). The impact of career development on employee performance: an empirical study of the public sector in Indonesia. International Review of Public Administration. 3(22): 276-299.

Nawawi, H. (2005). Manajemen Sumber Daya Manusia Untuk Bisnis yang Kompetitif. Cetakan Ke-4. Yogyakarta: Gajah Mada Univercity Press.

Nugroho, D. A \& Kunartinah. (2012). Analisis pengaruh kompensasi dan pengembangan karier terhadap kepuasan kerja dengan mediasi motivasi kerja. Jurnal Bisnis dan Ekonomi. 19(2):153-169.

Oduma, C. \& Susan. (2014). Influence of career development on employee performance in The Public University, a case of Kenyatta University. International Journal of Sciences Management and Entrepreneurship.1(2): $1-16$.

Omollo, P.A. (2015). Effect of motivation on employee performance of commercial bank in Kenya: a case study of Kenya Commercial Bank in Migori Country. International Journal of Human Resources Studies.5(2): 87-103.

Palgunanto, Y., Suparno, \& Dwityanto, A. (2010). Kinerja karyawan ditinjau dari gaya kepemimpinan transformasional. Jurnal Ilmiah Berkala Psikologi. 12(1):66-73. 
Parerung, A. (2014). Disiplin, kompensasi dan pengembangan karir pengaruhnya terhadap kinerja pada badan lingkungan hidup Provinsi Sulawesi Selatan. Jurnal EMBA. 2(4): 688-696.

Pillay, N. (2015). The relationship between career development and staff motivation in The South African Petroleum Sector: a case study of a Durban Refinery. Arabian Journal of Business and Management Review (Nigerian Chapter). 3(2): 1-51.

Pratiwi, D. (2015). Pengaruh kompensasi dan pengembangan karir pada kinerja karyawan dengan motivasi kerja sebagai variabel moderasi (Studi empiris pada DPPKAD Boyolali). Benefit Jurnal Manajemen Bisnis. 3(4): 25-38.

Ridwan, I.L., Susilo, H., \& Riza, M.F. (2014). Pengaruh motivasi terhadap kinerja karyawan (Studi pada PT Elsiscom Prima Karya, Kantor Perwakilan Surabaya). Jurnal Administrasi Bisnis. 13(1). 1-10.

Riyadi, S. (2011). Pengaruh kompensasi finansial, gaya kepemimpinan, dan motivasi kerja terhadap kinerja karyawan pada perusahaan manufaktur di Jawa Timur. Jurnal Manajemen dan Kewirausahaan. 13(1): 40-45.

Shahzadi, I., Javed, A., Pirzada, S.S., Nasreen., \& Khanam, F. (2014). Impact of employee motivation on employee performance. European Journal of Business and Management. 6(23): 159-167.

Suwandi. (2016). Pengaruh budaya organisasi terhadap prestasi kerja melalui kepuasan kerja. Analitika. 8(2): 140-147.

Zameer, A. Nisar \& Amir. (2014). The impact of the motivation on the employee's performance in Beverage Industry of Pakistan. International Journal of Academic Research in Accounting, Finance and Management Sciences. 4(1): 293-298. 